Környezetegészségügy - Eredeti közlemény / Environmental health - Original article

Magyar Donát1, Szigeti Tamás', Páldy Anna', Udvardy Orsolya', Zséli Györgyi’, Orlóci Lászlón',3

${ }^{1}$ Nemzeti Népegészségügyi Központ, Budapest - National Public Health Center, Budapest

${ }^{2}$ Eötvös Loránd Tudományegyetem, Botanikuskert, Budapest - Eötvös Loránd University, Botanical Garden, Budapest

${ }^{3}$ Magyar Díszkertészek Szövetsége, Budapest - Hungarian Ornamental Horticulturist Association, Budapest

\title{
A növények potenciális allergenitása - áttekintés és módszertani javaslat
}

\author{
Potential allergenicity of plants - review and \\ methodological proposal
}

\section{Összefoglalás}

A növényi pollen allergizáló képessége számos tényezőtől függ. E feltételek: a pollen allergiás immunválasz kiváltására alkalmas anyagot tartalmazzon, a pollent nagy mennyiségben termelje a növény, a pollenszem kis méretű legyen és könnyen, nagy mennyiségben szálljon a levegőben, a növény gyakori, tömegesen előforduló fajba tartozzon. E tényezőket külön súlyozva kiszámítható az egyes növénytaxonok potenciális allergenitása. Dolgozatunkban a szakirodalomban fellelhető módszereket hasonlítjuk össze, és keressük a megfelelő eljárást, amely a növények ültetésére, kereskedelmére irányuló jogi szabályozás alapja lehetne. Az irodalmi áttekintés alapján nem találtunk olyan jelenleg létező módszert, amely a jogi szabályozás követleményeit kiegégítheti (megfelelő 
bizonyítékok felsorolása és reprodukálhatóság), ezért kidolgoztunk egy saját eljárást a növények potenciális allergenitásának kiszámítására.

Kulcsszavak: allergia, pollen, allergenitás, növényzet, tájékoztatás

\section{Summary}

The allergenicity of plant pollen depends on a number of factors, namely the followings: the pollen must contain an allergenic substance capable of triggering an immune response, the pollen must be produced in large quantities by the plant, the pollen grain must be small and bouyant, to be present in large quantities in the air, the plant must belong to a common species. By weighting these factors separately, the potential allergenicity of each plant taxon can be calculated. In our review we compare the methods found in the literature and look for the appropriate procedure, which could be the basis of the legal regulation for planting and trading plants. Based on the literature review, we did not find any currently existing method that could meet the requirements of the legislation (providing appropriate evidence and reproducibility), so we developed our own procedure to calculate the potential allergenicity of plants.

Keywords: allergy, pollen, allergenicity, vegetation, communication 
Környezetegészségügy - Eredeti közlemény / Environmental health - Original article

\section{EGÉSZSÉGTUDOMÁNY}

$$
\text { 2020;64(4): 30-56 }
$$

\section{HEALTH SCIENCE}

Közlésre érkezett: 2020. október 29.

Submitted: 29 October 2020

Elfogadva: 2020. november 30.

Accepted: 30 November 2020

Levelezési cím/Correspondence:

$$
\text { Dr. Magyar Donát }
$$

Nemzeti Népegészségügyi Központ 1097 Budapest, Albert Flórián út 2-7. E-mail: magyar.donat@gmail.com Tel.: +36 1 476-1100/2210

\section{Bevezetés, célkitűzés}

Számos növényfaj pollenje allergiás megbetegedést (pollinosis) okoz érzékeny személyekben immun-mediált reakciók révén 1 . A növények allergizáló képessége számos tényezőtől függ. A szélbeporzású növények általában nagy mennyiségü pollent termelnek, melyeket a légáram könnyen szállít. Ezzel ellentétben a rovarmegporzású növények pollenszemei ritkán fordulnak elő a levegőben. A növényenként kibocsátott pollenmennyiség mellett a pollenszemekben található allergén fehérjék minősége és mennyisége is fontos tényező. Következésképpen az egyes növényfajok vagy fajták (a továbbiakban: taxonok) különböző mértékben képesek allergiás reakciók kiváltására. Ezek alapján az egyes taxonok alacsony, közepes, magas és nagyon magas allergenitású kategóriákba sorolhatók. A növények osztályozására, az általuk kiváltható tünetek súlyossága alapján allergenitási kategóriákba való sorolására többen tettek kísérletet 23,4,5,5,6,7,8,9,10,11,12,13,14,15,16,17. A növények ilyen allergén kategorizálási rendszereit különböző célokra használják, pl. növények ajánlására kertek, vagy akár városi parkok kialakításához.

Az allergén növények felismerése fontos a betegek számára, mivel így csökkenthetik a pollenexpozíciót, ezáltal az allergiás tünetek kialakulásának megelőzésében vagy azok mérséklésében ez a tudás jól alkalmazható. 
Az egyes növénytaxonok allergenitására vonatkozó információval gyakran találkozhatunk a pollenjelentésekben és a pollenhelyzet elörejelzésével foglalkozó honlapokon ${ }^{18}$. Az egészségügyi intézményekben, például a gyógyszertárakban és allergológiai rendelőkben kihelyezett plakátokon, szórólapokon, pollennaptárakon is sokszor megjelenik a növények allergenitására vonatkozó tájékoztató információ. Számos allergén növényfaj visszaszorítására tettek már kísérletet, melyet többnyire az is indokolttá tesz, hogy a szóban forgó faj gyomnövényként jelentős mezőgazdasági kárt okoz. Az inváziósan terjedő gyomok között allergén pollent termelő fajok is előfordulnak - elég csak a jól ismert parlagfüre gondolnunk. E gyomnövény mind az egészségügyben, mind a mezőgazdaságban komoly gazdasági károkat okoz. A parlagfú Észak-Amerikából származik, ahonnan az 1920-as években gabona szállítmányokkal behurcolták. Azonban sok olyan inváziós növényfaj is létezik, amelyet szándékosan telepítettek be, úgy, hogy az ebben közremúködők nem tudtak a növényfaj inváziós és/vagy allergizáló képességéről (PI. kanadai aranyvessző (Solidago canadensis), fényeslevelű fagyal (Ligustrum lucidum), ártéri japánkeserüfü (Fallopia japonica). Az újonnan betelepített növényfajok rövid időn belül súlyos egészségterhet jelentő allergénné válhatnak ${ }^{19}$. Az allergenitásra vonatkozó tájékoztatás hatékony eszköz lehet e növények nemkívánatos megjelenésének és elterjedésének megelőzésében. $E$ cél érdekében egyes külföldi forgalmazók a dísznövényeket és a palántákat az allergenitásukra vonatkozó vevői tájékoztatóval látják el. A virágüzletekben és a kertészeti árudákban kihelyezett tájékoztatók többnyire a növény kedvező tulajdonságait emelik ki (azaz az címkén olvasható felirat szerint a növény „nem pollentermelő" vagy "nem allergén" esetleg „allergiás betegeknek ajánlott”). Azonban találkozhatunk olyan esettel is, amikor az allergia veszélyére figyelmeztetik a vásárlókat. Az allergenitásra vonatkozó információk kertészkedők részére is hozzáférhetők különféle kiadványok formájában. Ezek a tájékoztatók növénylistákat tartalmaznak, amelyek szintén hasznosak azoknak, akik aller- 
Környezetegészségügy - Eredeti közlemény / Environmental health - Original article

génmentes kertet szeretnének létrehozni. Az erre vonatkozó kiadványok többnyire lakosságnak íródott könyvek formájában hozzáférhetők (1. ábra), de időnként cikkek is megjelennek e témában, valamint külföldi honoldalakon is találhatunk erre vonatkozó ajánlásokat $3,5,6,7,14,16,20,27$.

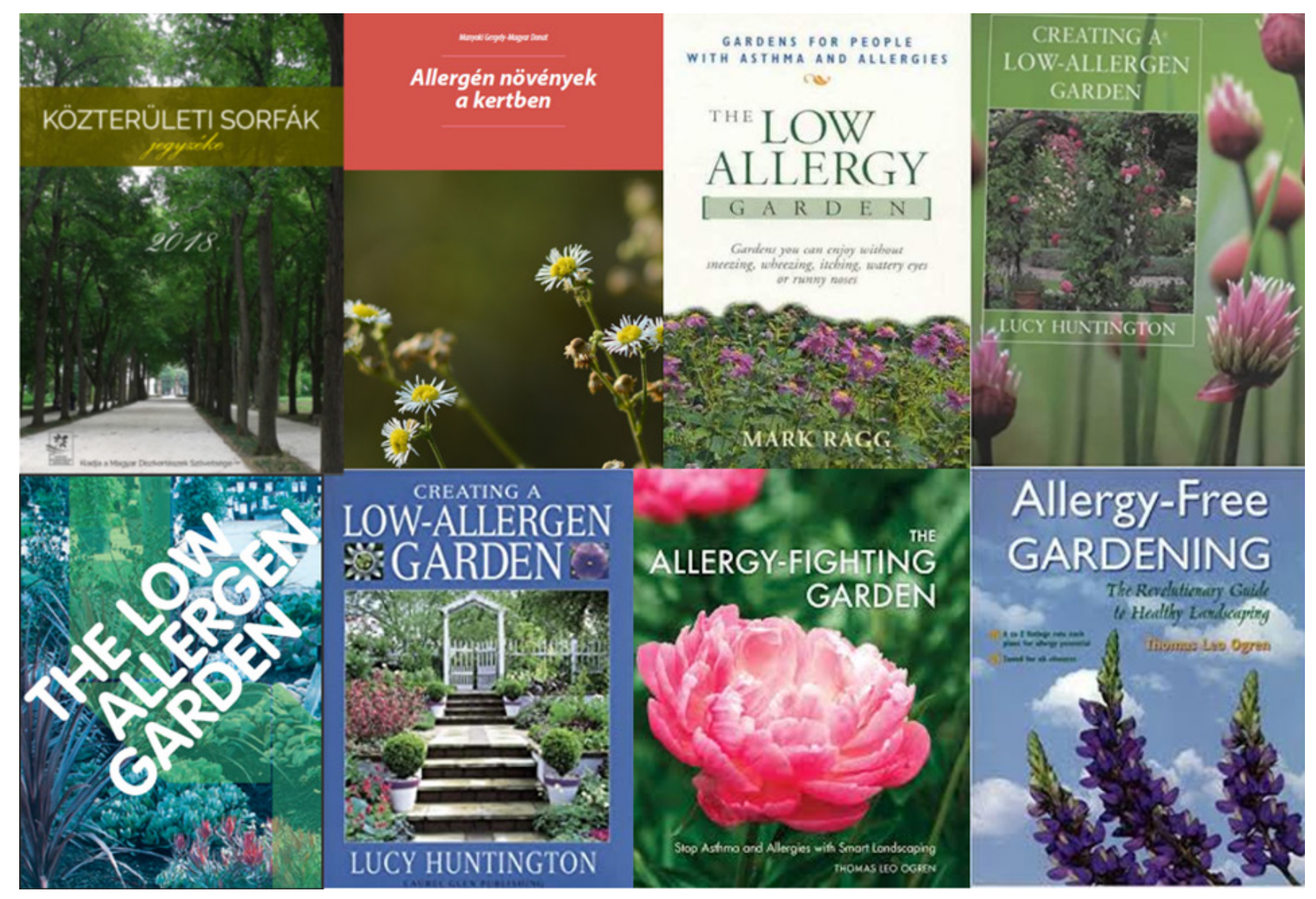

1. ábra: Az allergénmentes zöldfelületek kialakítására vonatkozó irodalom nagyon népszerü, ezt mutatja a számos e témában megjelent kiadvány

Figure 1. The literature on the design of allergen-free green areas is very popular, as publications show. 
A világ népességének nagy része városi környezetben él, ahol a zöldfelületek emberi tevékenység eredményeként jöttek létre. Az egyes önkormányzatok sokat tehetnek az allergénterhelés csökkentése érdekében, amennyiben felhagynak az allergén fajok ültetésével, és növénytelepítés előtt figyelembe veszik az allergén fák listáját 22. E célból készült el az EFOP-1.8.0.-VEKOP-17-2017-00001 azonosítószámú, az „Egészségügyi ellátórendszer szakmai módszertani fejlesztése" címü kiemelt projekt aerobiológiai munkacsoportjának és a Magyar Díszkertészek Szövetségének közös munkájaként a Közterületi Sorfák Jegyzékében szereplő ajánlás 2019-ben. E kiadvány a hazánkban gyakori sorfák esetében ad tájékoztatást arról, hogy az adott fa ültetése allergológiai szempontból javasolt-e vagy nem 23. Ebben az anyagban azonban még nem szerepeltek allergenitási kategóriák, s az ajánlás alapját képező módszer és szakirodalom bemutatása sem volt a kiadvány célja. Emellett azt is hangsúlyozzuk, hogy az ajánlások nem támogatják a fák kivágását, hanem allergén fák ültetésének csökkentését célozzák.
A vegetáció a globális felmelegedés függvényében változik. Az elörejelzések szerint a mérsékelt övben honos fajok elterjedése, a természetes populációk mérete jelentősen csökkenhet. Ezzel szemben a melegebb éghajlati övben élő fajok új területeket hódíthatnak meg. Hazánk területén is számíthatunk a melegebb éghajlati övek növényeinek felbukkanására, megtelepedésére ${ }^{24,25}$. A klímaváltozásra való felkészülés keretében kertészek, tájrendezők olyan növényeket keresnek, amelyek képesek ellenállni az éghajlatváltozásnak vagy pótolják a kiszoruló őshonos növényeket. E növényfajok kiválasztásában fontos szempont kell, hogy legyen a faj vagy fajta alacsony allergenitása. Ma még szinte teljesen hiányzik az allergenitásra vonatkozó információk felhasználása a zöldfelület gazdálkodásban, valamint a városi ökoszisztéma-szolgáltatások tervezésében és értékelésében ${ }^{26}$. Azonban e szempontot fontos figyelembe venni, mert a megfelelő taxonok kiválasztásával, a városi zöldterületek tervezése és kezelése révén a városi levegő allergéntartalmát jelentősen lehetne csökkenteni ${ }^{9,17}$. 


\section{A növénytaxonokat allergén kategoriákba soroló rendszerek áttekintése}

Annak érdekében, hogy megfelelő módszert találjunk a hazai növénytaxonok allergén kategóriákba sorolására, áttekintettük a szakirodalmat. Bergmann 9 javaslata alapján elvetettük azokat a módszereket, amely csak két kategóriát (allergén, nem allergén) adnak meg 2,22,13,15,15,16. A módszer kiválasztásának feltételei között szerepelt az is, hogy a szerzők az egyes növények allergenitásának leírásakor az elsődleges hivatkozást adják meg, továbbá a közleményük tartalmazza a kategóriába sorolás számítási módszerét. Sajnos az eddig megjelent közlemények egyike sem teljesítette ezt a két követelményt. Legtöbbjük egyáltalán nem, vagy csupán másodlagos hivatkozásokat tartalmazott a növények allergenitására vonatkozóan, vagy nem nyújtott egyértelmű (reprodukálható) leírást a számítási módszerről. Mindazonáltal a szakirodalomban szereplő jelentősebb rendszerekről egy rövid áttekintést adunk az alábbiakban.
Az egyik első tanulmány, ami a növények allergenitás szerinti kategorziálását túzte ki célul, az amerikai Thomas Leo Ogren amerikai kertész Allergénmentes kertek címú összefoglalója 5. A leírt növénytaxonok allergenitási tulajdonságait egyes országokban a kertészeti kereskedelemben is megjelenítik, így segítve elő az allergénmentes vagy kevésbé allergizáló kertek kialakítását. E kézikönyv segítségével a kertészkedők tájékozódhatnak az adott növény által képviselt egészségkockázatról. Az Ogren-féle skálán (OPALS - Ogren Plant AIlergy Scale) besorolt növényfajok, kertészeti fajták, illetve változatok száma kb. 3000 (a könyv föként amerikai fajokat rendszerez). A skála 10 kategóriába sorolja a növényeket, allergia kiváltása szempontjából a legkisebb érték a legkedvezőbb, míg a legnagyobb a legrosszabb tulajdonságokat jelzi. Az osztályozás alapja elsősorban a növénymorfológia és a habitus. A figyelembe vett tényezők száma nagyon magas (több mint 60), leírásuk a könyvben több oldalt tesz ki, ezért ezek közül csak néhányat említünk: beporzás típusa; növényrendszertani besorolás; a virág vagy virágzat 
megjelenése (méret, alak, szín); a porzó elhelyezkedése a virágon belül; a virágzási periódus hossza; a pollenszem mérete, tömege; a pollenszem szárazsága, ill. ragadóssága; a pollenszem alakja; virágillat; virágzási napszak. A morfológiai tulajdonságok többsége, amelyeket az OPALS figyelembe vesz, valóban nagyban hozzájárulhat az allergia fokozódásához. Például a porzók elhelyezkedése a virágon belül, a pollenszem alakja, nagysága, ragadóssága, felszíne befolyásolja azt, hogy a légáramlatok által milyen messzire képesek eljutni a pollent kibocsájtó növénytől, az meddig képes a levegőben maradni. A virág illata, megjelenése arra utal, hogy rovar vagy szél által terjed-e inkább az adott növény virágpora. Azonban a rendszer hiányosságaként kell megemlítenünk, hogy nem adja meg, milyen súllyal szerepelnek e tényezők a kategória számításban. Az OPALS másik fő hiányossága, hogy a számítás módját nem közli. E hiányosságok korlátozzák az OPALS használatát, mivel nem terjeszthető ki újabb növényfajokra, illetve a számítás nem ellenőrizhető és nem ismételhető meg. Emellett szakirodalmi hivatkozások sem állnak rendelkezésre a növény allergenitására vonatkozóan. A pollenszemek tekintetében a leglényegesebb szempont a pollen allergén fehérje tartalma, illetve a peptidek/fehérjék immunválaszt kiváltó képessége, amely figyelembevételéről nem esik szó a szempontok felsorolásában. Ogren (és mellette más szerzők is, pl. Thompson és Thompson ${ }^{27}$ ) szerint a pollenkibocsátásban a porzószál hoszsza is jelentős szerepet tölt be. E feltételezést arra alapozzák, hogy a hosszabb porzószálról könnyebben levegöbe jut a virágpor. E szempontot számos szélés rovarbeporzású növény esetén megvizsgáltuk, és arra a következtetésre jutottunk, hogy a porzószál hossza nincs összefüggésben a beporzás típusával. Ehhez a meglátásunkhoz azok a rovarbeporzású fajok szolgáltatnak bizonyítékot, amelyek légköri koncentrációja igen alacsony, ugyanakkor hosszú porzószállal rendelkeznek (például Cornus alba, C. sanguinea, Hedera helix, Koelreuteria paniculata, Prunus maackii 'Amber Beauty', Sorbus × thuringiaca 'Fastigiata'). Továbbá, az OPALS rendszer nem csupán azokat a botanikai jellemzőket veszi figyelembe, amelyek aller- 
giás reakció kialakítását segíthetik elő, hanem például a mérgező hatást vagy kellemetlen illatot is beépíti az értékelésbe, ezért nem használható tisztán az allergológiai kockázat értékeléséhez. Ogren 10-es értékelő skálája viszonylag szélesnek tekinthető. Gyakorlati szempontból, a tünetek erőssége alapján célszerünek túnik kevesebb kategóriát és tágabb osztályozási szinteket kialakítani, mint ahogy más szerzők általában a 10 helyett 4-5 kategóriába csoportosítják a növényeket.

Paloma Cariñanos spanyol kutató és munkatársai szintén jelentős előrelépést tettek a növények allergén minősítésével kapcsolatban egy másik megközelítésben. E kutatócsoport elsősorban a városi parkok értékelésével foglalkozik, a parkokban található növények által kibocsátott pollen okozta allergénterhelés becslésével. Az általuk kidolgozott zöldfelület-értékelési modell ( $\left(_{\text {UczA }}\right)$ részeként a növények allergén kategóriákba sorolását is elvégezték. A Cariñanos-féle rendszerben az allergenitási értéket meghatározó képlet ismert. Az egyes növényfajokra vonatkozó allergén érté- ket (Potential Allergenic Value (PAV)) a növényfaj pollenkibocsátásra vonatkozó jellemzői határozzák meg, amelyek a beporzás típusa (type of pollination (tp)), a virágzási periódus hossza (duration of pollination period (dpp)) ${ }^{28}$, és a növény allergén potenciálja (allergenic potential (ap)). A PAV értéke a beporzási típus által kapott érték, a virágzási periódushossz számértéke és a növényre jellemző allergén potenciál értékének a szorzata adja meg: PAV $=\mathrm{tp} \times \mathrm{dpp} \times$ ap; PAVmax=3 × $3 \times 4=36$. A PAV értéke alapján a potenciális allergenitást 5 kategóriába sorolják (semleges, alacsony, mérsékelt, magas, nagyon magas). A módszert leíró cikkben referenciák is szerepelnek, azonban komoly hiányosságuk, hogy ezek nem elsődleges hivatkozások, és nagyrészt nem az egyes növények allergenitására vonatkozó bizonyítékokat tartalmazzák.

Krunica Hruska rendszere elsősorban az olaszországi vegetáció esetében használható. A rendszer megalkotásában egyes vegetációk allergenitásának meghatározása volt a cél, ezért főként egy adott időszakra vonatkozóan ve- 
szi figyelembe az adott növényfaj gyakoriságát. A szerző három allergenitási kategóriát állapított meg: nem, vagy gyengén allergén, mérsékelten allergén és erősen allergén kategóriát. $E$ kategóriákat a szerző több tényező figyelembevételével határozta meg. Az első tényező a növény életciklusa (egynyári, kétéves vagy évelő, amely a hozzárendelt számérték szerint 1, 2 vagy 3). A második a virágzási periódus hossza, ami, ha kevesebb, mint egy hónap, akkor 0,5-ös, ha több mint egy hónap, akkor 2-es számértéket kap. Az allergenitás szempontjából harmadik tényezőként figyelembe veszi az allergén fehérjék közötti keresztreakciók meglétét (ha nem mutattak ki keresztreakciót, akkor 0, ha kimutattak, akkor 1-es értékeket vesz számításba). A negyedik szempont a borítottsági százalék, amely egy adott területen megjelenő fajra vagy taxonra vonatkozik. Ha az adott területen a kérdéses növény területi borítottsága kevesebb, mint 1\%, akkor ritkának tekinthető (ehhez 0,5-ös értéket rendel a szerző); ha 1-25\%-ban van jelen, akkor az elöfordulás közepes (ekkor a számérték 1); a 2550\%-nál a faj előfordulása gyakori (2); 50 - 75\%-nál nagyon gyakori (3); 75-100\%-nál tömeges (4) minősítést kap. A növényeket a négy szempont szerint jellemzi a rendszer, majd ezekhez a jellemzőkhöz rendelt számértékeket összeadja, ami megadja az adott növényfaj allergén indexét. Ha a növényfaj allergén indexe 1-3, akkor 1-es kategóriába, ha 4-6, 2-es kategóriába, ha 7-10, akkor 3-mas kategóriába sorolandó.

\section{Nicoleta lanovici 7 Romániában} dolgozó kutató rendszere nagyon hasonló Hruska rendszeréhez, célja szintén egy adott területen elhelyezkedő vegetáció allergenitásának meghatározása. A Hruska-féle rendszert annyiban továbbfejleszti, hogy a növényfaj gyakoriságát a pollenkoncentráció alapján határozza meg (az éves össz pollenkoncentrációt 0-0,99\%-át adó faj ritka $(0,5)$; 1-1,99\%: közepes (1); 2-4,99\%: gyakori (2); 5-10\%: nagyon gyakori (3), és 10\% felett: tömeges (4). Továbbá az allergenitásra vonatkozó kategóriákat használ: bizonytalan hatású (1); gyengén (2); mérsékelten (3) és erősen allergén (4). A növényeket e négy szempont szerint jellemzi a rendszer, majd ezekhez a jellemzőkhöz 
rendelt számértékeket összeadja, és ezek összege lesz az adott növényfaj allergén indexe (2 alatt 1-es kategória; 2,54,5 között 2-es kategória; 5-6 között 3-as kategória; 6,5- 7 között 4-es kategória).

\section{Ute Künkele és Josef Lecheler a} Ratgeber Pollenallergie für Patienten und Ärzte (1992) című könyvükben ${ }^{3}$, amelyet elsősorban az allergiáról, mint betegségről írtak, publikáltak egy összefoglaló táblázatot Közép-Európa lakosságának pollenérzékenységéről, valamint ennek alapján a legelterjedtebb növénytaxonok allergenitásáról. A növényeket 4 kategóriába sorolják, az alapján, hogy az allergiás lakosság mekkora százaléka mutatott allergiás reakciót az adott taxon pollenjével szemben. A besorolást Horak és Jäger 29 allergiatesztjei alapján állították fel. Öszszesen 31 taxont soroltak be „alacsony”, "közepes”, „magas” és „nagyon magas” allergenitású kategóriákba.

A pollenlibrary.com amerikai honlap adatbázisában több mint 1200 növényfaj található, amelyek pollenallergenitására vonatkozó információt a felhasználók kikereshetik. A honlap na- gyon népszerü, könnyen használható. $A$ különböző fajok 3 allergén kategóriába vannak rendezve (enyhén, közepesen és erősen allergén), illetve egyes növényeknél az „allergenitása nem ismert” megjelölés található. Az egyes növények általános allergenitása mellett aktuális pollenkoncentráció adatokat is szolgáltat az oldal az Amerikai Egyesült Államokra vonatkozóan. Azonban nem tájékoztatnak arról, hogy kik az oldal szerzői, milyen szempontokat használnak egy adott kategória felállításához, és milyen módon számítják ki az értékeket.

A felsorolt különböző kategóriarendszerekben a növények allergenitását illetően sok esetben eltérő értékeket találhatunk (2. ábra). A különböző szempontok, amelyeket az egyes rendszerek használnak, különféle erősségű allergenitást eredményeznek egy adott növényfajra. pl. az OPALS főként morfológiai szempontokat vesz figyelembe, míg mások egy-egy kisebb (Hruska-rendszer) vagy nagyobb (lanovici, Cariñanos) területre vetítve a vegetáció nagyságát és a fajok arányait is figyelembe veszik a számításaikban. 


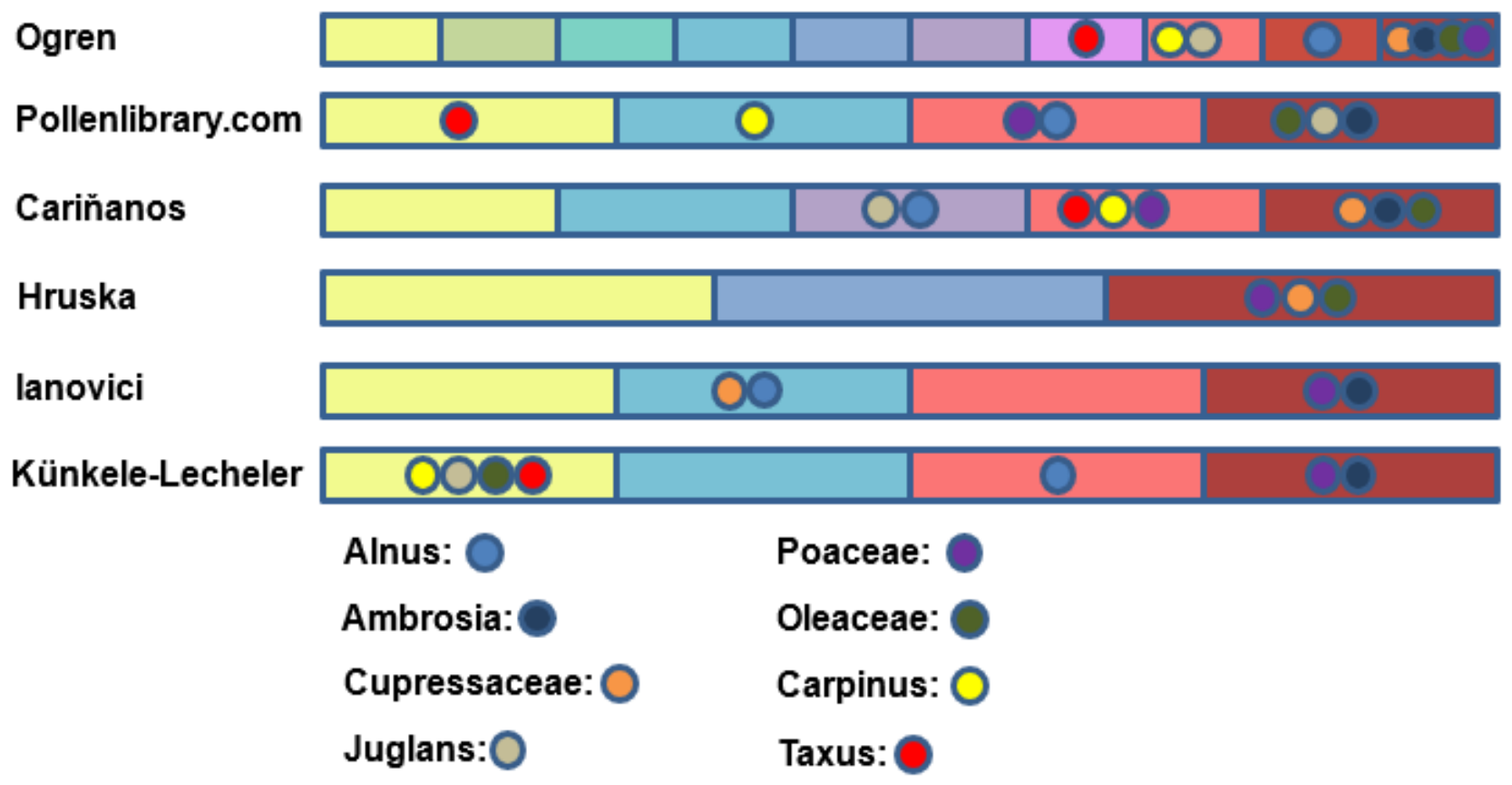

2. ábra: A kategóriarendszerek összehasonlítása 8 taxon esetében. E rendszerek eltérő célra történő kifejlesztése miatt az egyes fajok, illetve taxonok jelentős eltéréseket mutatnak az egyes besorolásokban. A téglalapok színe az allergenitás erősségét jelöli: sárga: nem allergén, kék: közepesen allergén, piros: erősen allergén, vörös: nagyon erősen allergén.

Figure 2. Comparison of categorization systems through 8 taxa. Due to the development of these systems for different purposes, individual species or taxa show considerable differences in the different systems. The colour of the rectangles indicates the strength of the allergenicity: yellow: non-allergenic, blue: moderately allergenic, red: highly allergenic; dark red: very highly allergenic 
A nagy különbségek további oka a különböző földrajzi, klimatikus, és vegetációtípusokon belüli növények osztályozása (3. ábra). Az OPALS és a pollenlibrary.com rendszert Észak-Amerikában, elsősorban az ottani növényfajok értékelésére dolgozták ki, ezért alkalmazásuk korlátozott. A cariñanosi rendszer elsősorban a mediterrán klímájú Spanyolországra vonatkoztatható. Künkele-Lecher a közép-európai térséget vizsgálta, az itteni kontinentális éghajlat növényzete által okozott allergiás reakciók alapján. Különböző klímákon eltérő a fajösszetétel és különböző a növények elterjedése, emiatt eltérő lehet a növény által termelt antigének minősége és mennyisége. Ennélfogva az egy földrajzi területen élő népesség az adott pollenviszonyok mellett más fajokra és eltérő mértékben szenzitizálódik.

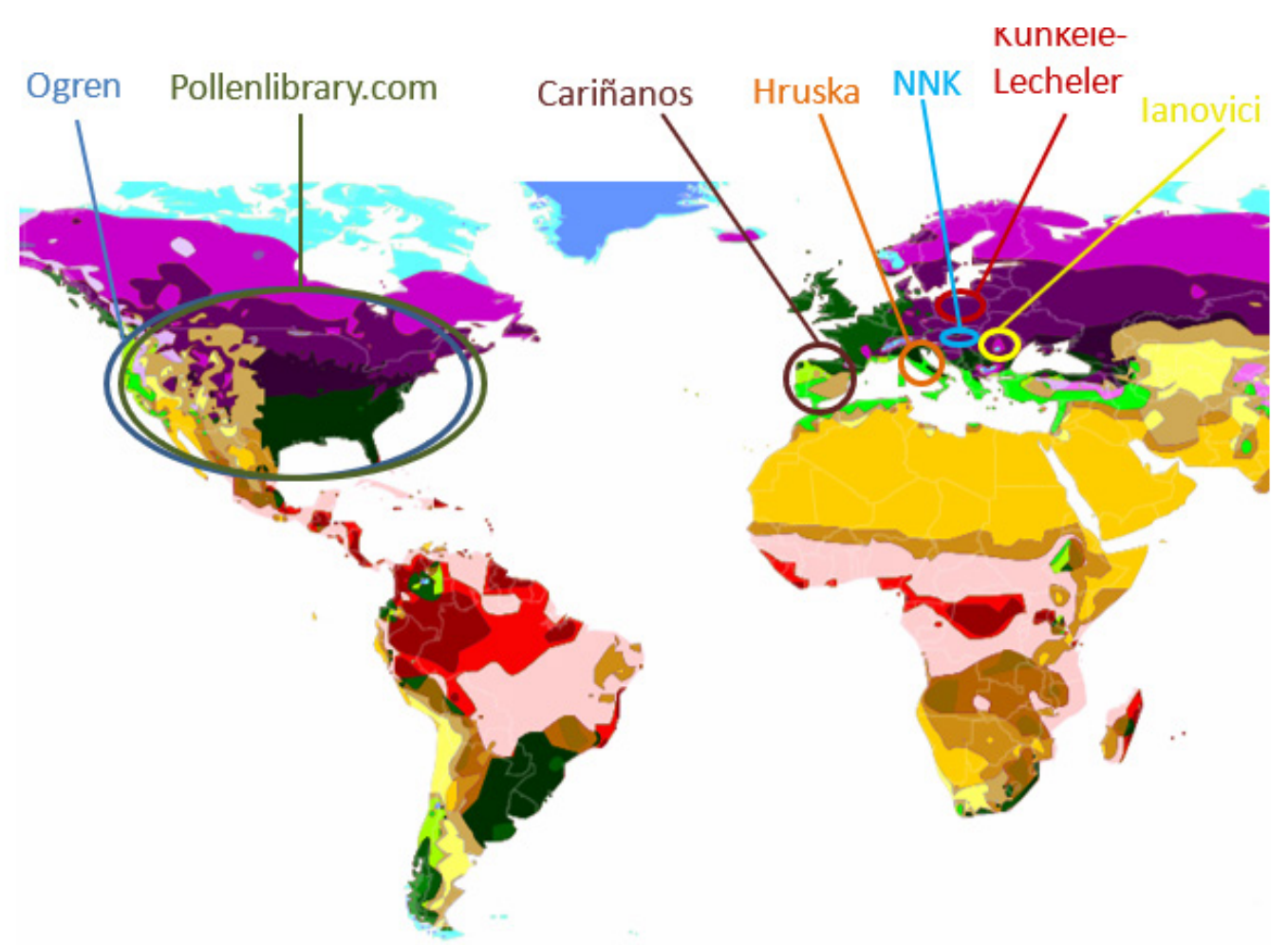

3. ábra: Az elérhető allergenitás-osztályozási rendszerek lehetséges alkalmazási területei Geiger-Köppen-féle klímatípus megoszlási térképen. (térkép: Wikipedia).

Figure 3.: Potential application areas of the available allergenicity classification systems on a Geiger-Köppen climate type distribution map. (map: Wikipedia). 
Mint említettük, a fenti rendszerek áttekintésének célja elsősorban az, hogy a hazai zöldfelület minősítés alapjául szolgáló módszert kiválasszuk. Ezek közül a Cariñanos és munkatársai ${ }^{37}$ által kidolgozott rendszer látszólag megfelelő lenne, azonban a másodlagos és harmadlagos hivatkozások használata komoly problémákat vet fel, amelyekre a következő fejezetben jobban rávilágítunk.

\section{A zöldfelületek jogi szabályozásának szempontjai}

Mára elegendő tudományos bizonyíték gyült össze arra vonatkozóan, hogy a nem megfelelően kialakított városi zöldfelületek pollenkibocsátása jelentős mértékben hozzájárulhat a lakosságot érő allergénterheléshez. A közegészségügyi problémák kezelésére a jogi szabályozás bevált és hatékony eszköznek tekinthető ${ }^{30}$. A szükséges rendelkezések szakmai hátterét a növénytaxonokra jellemző allergenitási fokozatok képeznék. Azonban ezek kidolgozása során figyelembe kell venni a rendelkezések lehetséges gazda- sági-társadalmi következményeit is. A fák allergenitási fokozatba sorolása gazdasági szempontból kedvezőtlenül érintheti a kertészeteket, faiskolákat, facsemete árudákat, amennyiben a rendelkezés következtében az erősen allergén fajok kereskedelmi forgalma csökken vagy megszünik, és ezáltal a több év munkájával előállított facsemeték egyik napról a másikra eladhatatlanná válnak. A pénzügyi következmények által legsebezhetôbb ágazatok közé tartoznak a faiskolák, ahol a fákat évekig nevelik a kívánt korig, amikor értékesíthetők ${ }^{31}$. Egy fafajtának az "erősen allergén" kategóriába sorolása és a piacról való kivonása pénzügyi problémákat okozhat a kertészeti szektorban. Ezt mutatja az a heves tiltakozás, amely az erre vonatkozó franciaországi jogszabályalkotást kísérte. A francia kertészek szakmai szervezete ugyanis 2019-ben kifogást emelt az ellen a rendelettervezet ellen, amelynek a célja az allergiára vonatkozó vásárlói tájékoztatók kötelezővé tétele volt az EU 2015/1535 irányelv 32 keretében. Hasonlóan reagált a Magyar Díszkertészek Egyesülete is az allergenitási fokozatok beveze- 
tésének javaslatára 2018-ban. Azonban a hazai "hadszintéren” ez a kezdeti ellentét az egyeztetések során egy nagyon hatékony szakmaközi együttmúködéssé alakult a közegészségügyi és a kertészeti szakterületek között, annak érdekében, hogy az átmenet fokozatos és gazdaságilag biztonságos legyen. Ugyanakkor ez az új irány lehetőséget teremt a növénynemesítők számára új, nem allergizáló, a hazai termőhelyi adottságoknak megfelelő fafajták létrehozására, értékesítésére. A szabályozás gazdasági következményeire tehát mindenképpen tekintettel kell lenni, s a bevezetést kísérő érdekek és ellenérdekek miatt az allergenitási fokozatokat úgy kell kialakítani, hogy azok szükség esetén jogi szempontból is védhetők legyenek. Ebböl következik, hogy az allergenitási fokozatoknak jogi szempontból is meg kell felelniük bizonyos elvárásoknak, vagyis teljesíteniük kell a bizonyítékok elfogadhatóságának jogi követelményeit.

Egy bizonyítási eljárás során egy állítás akkor tekinthető elfogadhatónak, ha az arra vonatkozó bizonyíték megfe- lelő mennyiségben és minőségben áll rendelkezésre. A bizonyítékok minimális mennyisége ez esetben legalább két olyan tudományos közleményt jelent, amely a növénytaxon allergenitását hitelt érdemlően igazolja. A bizonyíték minősége attól függ, mennyire tekinthetők a bizonyítékok megbízhatónak ${ }^{33}$. Az allergenitás megállapításához és az ezzel kapcsolatos döntések támogatásához tudományos szintű bizonyítékokra van szükségünk ${ }^{34,35}$. Ezért elvárható, hogy ezeket az állításokat, kijelentéseket nemzetközi folyóiratokban közzétett, eredeti közlemények eredményeire alapozzuk, egyúttal kizárjuk az eljárásból mindazokat a közleményeket, amelyek a másodlagos hivatkozásokra építkeznek.

Ortolani és munkatársai ${ }^{17}$ arra figyelmeztetnek, hogy az allergén kategorizálási rendszereket nem támasztják alá tudományos bizonyítékok. Irodalmi kutatásunk során erről mi magunk is meggyőződtünk. A közlemények csupán 53,8\%-ánál lehetett találni forrásmegjelölést, de ezek mindegyike másodlagos hivatkozás volt, amelyeknek 
gyenge a bizonyító ereje. A hivatkozások tanulmányozásával arra is fény derült, hogy ezek többsége (57\% -a) nem releváns (vagyis a közlemény nem tartalmaz eredeti információt a pollen allergizáló képességére vonatkozóan) és ezért sem alkalmas bizonyítéknak. Némelyik téves hivatkozás több rendszer irodalomjegyzékében is fellelhető. Tehát meglepő módon egyetlen olyan rendszer sincsen, amely a megfelelő bizonyítékokat használná a felsorolt növények allergenitásának bizonyítására.

A bizonyítás szempontjából az is fontos szempont, hogy az allergenitási kategória számítási módszere ismert és megismételhető legyen. Ennek oka az, hogy számos faj még nincs allergenitási kategóriába sorolva, ezeknél magunknak kell kiszámítani ezt az értéket. Az allergenitási kategóriába sorolás módszerének alkalmasnak kell lennie arra, hogy értékelni lehessen vele az országunkat is magában foglaló Pannon Biogeográfiai Régióban élő növényeket. A módszerrel szemben fontos követelmény a rugalmasság is. Az új növényfajták, kertészeti változatok szá- ma folyamatosan növekszik, és várható, hogy egyes újonnan megjelenő növények új populációkat hoznak létre.

Kumar és munkatársai ${ }^{36}$ szerint alapvetően két megközelítés létezik a zöld infrastruktura fejlesztések kezdeményezésére: alulról felfelé (lakosság, civil szervezetek felől érkező igények) és fentről lefelé (a kormány által irányított, szabályozás vagy pénzügyi támogatás révén). Nyilvánvaló, hogy a legtöbb allergén kategorizálási rendszert (bár kiváló tudósok készítették), nem úgy hozták létre, hogy a jogalkotás alapjává váljanak. Néhányat sikeresen használnak az alulról felfelé mutató kezdeményezések, azonban ezek célja nem a jogi szabályozás (hanem például a betegek vagy a vásárlók tájékoztatása). A felülrôl lefelé irányuló megközelítést célzó fellépéseknek azonban szigorú követelményei vannak, meg kell felelni a fent részletezett megfelelőségi kritériumoknak.

Célunk tehát egy olyan allergén kategorizálási rendszer létrehozása, amely megfelelő bizonyítékokon alapul, reprodukálható, rugalmas, ezáltal különböző 
biogeográfiai területeken és akár új növénytaxonok esetében is használható a zöldfelületek minősítésére és a felülről lefelé ható szabályozás kialakítására.

\section{Módszertani javaslat a potenciális allergenitás kiszámítására}

Az új, a jogszabály alkotási igényeknek is megfelelő allergén kategorizálási rendszer kidolgozása az EFOP-1.8.0.VEKOP-17-2017-00001 azonosítószámú, az „Egészségügyi ellátórendszer szakmai módszertani fejlesztése" címü kiemelt projekt keretében kezdődött el, és közegészségügyi szakemberek, aerobiológusok, kertészek és zöldfelület gazdálkodási szakemberek együttmúködésével alakítottuk ki. Az új rendszer a Pannon biogeográfiai régióban található növénytaxonok allergenitására vonatkozó eredeti közlemények irodalmi kutatásán, valamint e növények közvetlen fenológiai megfigyelésén és müszeres aerobiológiai mérési adatok elemzésén alapul. A korábbi allergén kategorizálási rendszerekben alkalma- zott tényezőket szintén figyelembe vettük 5,37. A tényezők meghatározásának részletes módszereit az alábbiakban ismertetjük.

\section{Allergizáló képesség/ Immunogenitás}

Az immunogenitás a pollenfehérje azon képessége, amellyel allergiás immunválaszt (IgE antitest termelődést) indukál 38. A klinikai és epidemiológiai szakirodalomban az egyes növénytaxonok immunogenitását bizonyító eredeti közleményeket kerestünk. A szakirodalom felkutatását különböző adatbázisokban végeztük: Allergome adatbázis (http:// www.allergome.org); a WHO / IUIS allergén nomenklatúra albizottság adatbázisa (http://www.allergen.org/) és Google Scholar, ahol az alábbi keresőszavakat használtuk: a növény latin neve + „pollen" + "allergy" és a növény angol neve + „pollen” + „allergy”. Csak a referált folyóiratokban szereplő adatokat fogadtuk el, azaz minden növénytaxonhoz elsődleges hivatkozásokat rendeltünk bizonyítékként. Nem használtunk ún. „szürke irodalmat" vagy másodlagos referenciákat tartalmazó közleményeket 
(Benzies és mtsai ajánlásai ${ }^{39}$ alapján).

Az immunogenitási faktor (IM) értéke 0 , 1,5 és 2 lehet; ahol:

0 = nincs bizonyíték az adott növényfaj immunogenitására.

1,5 = valószínúleg immunogén, de erre nincs közvetlen vagy elegendő bizonyíték. Ez a szint a következőket foglalja magában: a) hibrid taxonok, amelyek esetén a szülő fajok immunogenitása bizonyított, b) a taxon immunogenitása nem bizonyított, viszont az (általában nemzetségi szinten) rokon fajok immunogenitása már bizonyított, vagy c) a taxon olyan családba tartozik, ahol a keresztreakció általánosan elterjedt. A minimális követelmény legalább két olyan közlemény, amely leírja a (szülői, nemzetségi vagy családi szinten) rokon taxonok immunogenitását.

2 = az adott növényfaj immunogenitását legalább két független közlemény közli. A második cikk esetében rokon taxon immunogenitásáról szóló közlemény is elfogadható.

\section{Morfológia}

A szélbeporzású növények nagyobb mennyiségú pollent termelnek és bocsátanak ki, mint a rovarbeporzású fajok - ennek oka, hogy a széllel terjedő pollenszemek kisebb eséllyel jutnak a bibére ${ }^{40}$. A virágok és a virágpor alakja, felépítése összefüggésben áll a beporzás módjával. A virágok és a pollenszemek morfológiai vizsgálatát az EFOP-1.8.0.VEKOP-17-2017-00001 azonosítószámú, az „Egészségügyi ellátórendszer szakmai módszertani fejlesztése" címü kiemelt projekt keretében létrehozott pollen referencia gyűjtemény (amely több mint száz növényfaj pollenszemeit tartalmazza) valamint a palinológiai szakirodalom alapján végeztük 12,41,42,43,44, $45,46,47,48,49,50,51,52$.

A morfológiai tényező (Mo) értékei 1, 1,5 és 2; ahol:

1 = entomofil taxonok (rovarbeporzású taxonok); a virágok általában illatosak és / vagy nagy sziromlevelekkel rendelkeznek, és / vagy a pollenszem felületét ragacsos anyag borítja (pollenkitt, trifin) és / vagy hosszú (> $2 \mu \mathrm{m}$ ) tüskék díszí- 
tik és / vagy a pollen átmérôje nagyobb, mint $40 \mu \mathrm{m}$, és nincs légzsákja.

1,5 = ambofil (vegyes beporzású) taxonok; a virágok általában illatosak, a pollenszem általában ragacsos és kis átmérőjü (<40 $\mu \mathrm{m})$, és / vagy tüskékkel más kiemelkedő felszíni rajzolattal díszítettek, azonban ezek viszonylak kisméretűek (<2 $\mu$ m hosszúak).

2 = anemofil (szélbeporzású) taxonok; gyakran lombfakadás előtt virágzanak. A pollen könnyű és száraz, alacsony fajsúlyú és / vagy kisméretü (általában> 40 $\mu \mathrm{m}$ ), vagy légzsákokkal, és / vagy (majdnem) sima felülettel rendelkezik.

\section{Pollentermelö képesség}

Az egyes növényfajok pollentermelő képessége jelentősen különbözhet ${ }^{54}$. A pollentermelő képességre vonatkozó megfigyeléseket különböző forrásokból nyertük. Számos megfigyelési adat származik a Törökszentmiklós Mezőgazdasági Kft. által vezetett „Tudáspark” fagyüjteményéből, amely a Pannon biogeográfiai régió városi fasoraiban gyakori fafajokat tartalmazza (http:// tmrt.hu/ginop-hu/). Ezenkívül megfigyeléseket végeztünk a Budai Arborétumban ((47.0723, 20.2945, 47.481341, 19.040739) és az ELTE Botanikus Kertjében (47.484224, 19.085329). Emellett áttekintettük a vonatkozó szakirodalmat is 19,53,54,55,56,57,58,59,60,61,62 - Magyar Dísznövények Fajtagondnoksága - Nemzeti Fajtagyüjtemény adatbázisa).

A pollentermelő képességet (Po) 0, 0,5, 1 és 2 szintre osztottuk fel; ahol:

$0=$ nincs pollentermelés, mivel a növénynek kleisztogám virágja van, vagy hiányzik, vagy a porzók szirmokká fejlődnek (pleniflora vagy ponpon virágú fajták), vagy a pollenkibocsátást más genetikailag stabil tulajdonság gátolja, vagy a beporzás nem lehetséges, mert a növény egy stabilan egylaki faj termős példánya vagy egy stabilan nőivarú kertészeti változat.

0,5 = csökkentett pollentermelésú fajta; 1 = pollentermelő taxon (kertészeti változatok esetén a pollentermelés hasonló, mint az alapfaj esetében).

2 = kertészeti változatok, fajták, amelyek jelentősen nagyobb pollentermeléssel rendelkeznek, mint az alapfaj. Azokat a 
Környezetegészségügy - Eredeti közlemény / Environmental health - Original article

barkás növényeket is ide soroljuk, amelyek pollentermelése nagyobb, mint 2 millió pollen / barka.

\section{A potenciális allergenitás}

A fenti paraméterek felhasználásával a potenciális allergenitást (PA) az alábbi módon számolhatjuk ki:

$P A=I m \times M o \times P o$

A számítás eredményeként a PA maximális értéke 8 , de ezt az eredmények jobb áttekinthetősége érdekében öt kategóriába soroljuk (1. táblázat). Egyes fajok esetén nincs elegendő információ a besoroláshoz, ezek további vizsgálatot igényelnek.

A potenciális allergenitás tehát egy adott növénytaxon lehetséges allergiakiváltó képességét jelenti a növény pollenszemeinek allergizáló tulajdonsága, a pollen morfológiai tulajdonságai és pollentermelése alapján.

1. táblázat: A növények potenciális allergenitásának (PA) kategóriarendszere

\begin{tabular}{|llll}
\hline PA & allergenitás & kategória & jelölés \\
\hline 0 & nem allergén & 0. & világos zöld \\
\hline $0<P A \leq 2$ & kis mértékben allergén & 1. & zöld \\
\hline $2<P A \leq 4$ & mérsékelten allergén & 2. & sárga \\
\hline $4<P A \leq 6$ & erösen allergén & 3. & narancssárga \\
\hline $6<P A \leq 8$ & nagyon erősen allergén & 4. & piros \\
nem ismert & további vizsgálatot igényel & - & szürke \\
\hline
\end{tabular}

Table 1. Categorization system of potential allergenicity (PA) of plants

\begin{tabular}{|c|c|c|c|}
\hline PA & allergenicity & category & $\begin{array}{l}\text { Color } \\
\text { code }\end{array}$ \\
\hline 0 & non allergenic & 0 & Light green \\
\hline $0<P A \leq 2$ & low & 7 & green \\
\hline $2<P A \leq 4$ & medium & 2 & yellow \\
\hline $4<P A \leq 6$ & high & 3 & orange \\
\hline $6<P A \leq 8$ & very high & 4 & red \\
\hline n.d. & further studies & ed & gray \\
\hline
\end{tabular}


A potenciális allergenitás értékeit az egyes növénytaxonokra vonatkozóan az interneten ${ }^{63,64}$ tettük közzé; a frissítéseket a Közterületi Sorfák Jegyzékében közöljük. Annak érdekében, hogy a fellelhető egyéb allergenitási indexektől (OPALS, PAV, stb., lásd fentebb) megkülönböztessük, az általunk készített potenciális allergenitási indexet az angol jelentés alapján képzett mozaikszó alapján "CARE-S" néven is hivatkozzuk (CAtegorization System for REgulation of Allergenic Plants by Strength of Evidences).

\section{Alkalmazási lehetőségek}

A potenciális allergenitás a földrajzi környezettől független, pusztán a növény örökletes adottságait veszi figyelembe, ezért alkalmas a külföldről származó allergén növényfajok behozatalának megakadályozására, elterjedésük viszszaszorítására, még azelőtt, hogy hazánkban elterjedve tömeges megbetegedéseket okozzanak.

A potenciális allergenitás értékelése révén szabályozhatóaz egyes növényfajták behozatala, szaporítása, kereskedelme, felhasználásuk aránya a zöldfelületek létesítésében, és kedvező irányba mozdítható el a növényfajták nemesítése, mivel az allergénmentes fajtákat részesíti előnyben. Az allergénmentes fajták választékának növekedésével a városi zöldfelületek mérete és biodiverzitása megőrizhető, mindemellett a pollenterhelés csökkenésére számíthatunk ${ }^{65}$. A klímaváltozás jelentősen átalakíthatja hazánk növényzetét. Az erre való felkészülésben fontos, hogy jogi eszközökkel szabályozzuk, mely allergén, invazív növényfajokat tartsuk határainkon kívül, és mely hasznos növényeknek engedjünk szabad utat ${ }^{66}$. A jogszabályok elsősorban a közterületek fásítására gyakorolhatnak kedvező hatást. Azonban, ha a potenciális allergenitás érték lakossági kommunikációban és vásárlói tájékoztatókban is megjelenik, a magánkertek allergén kibocsátása is csökkenhet.

A fentieken túl a potenciális allergenitás értékelésének van egy további haszna is. A növények allergenitási értékei a zöldfelületek minősítésében is felhasználhatóak, - e lehetőséggel következő cikkünk részletesen foglalkozik - ${ }^{65}$. 


\section{Nyilatkozatok}

A szerzők nyilatkoznak arról, hogy a közlemény más folyóiratban korábban nem jelent meg, és máshová beküldésre nem került. A szerzők nyilatkoznak arról is, hogy a cikk végleges változatát valamenynyi szerző elolvasta és jóváhagyta.

\section{Anyagi támogatás}

A módszer kidolgozását az EFOP1.8.0.-VEKOP-17-2017-00001 azonosítószámú, az „Egészségügyi ellátórendszer szakmai módszertani fejlesztése" címü kiemelt projekt biztosította.

\section{Szerzői érdekeltségek}

A szerzőknek nincsenek érdekeltségei.

\section{Irodalomjegyzék}

1. Fireman, P.: Pediatric otolaryngology vol. 2 ( $4^{\text {th }}$ ed.). W. B. Saunders. Philadelphia, 2002, 1065.

2. Spieksma F. Th. M.: Allergenic plants in different countries in Pollinosis. Ed.: Falagiani, P. CRC Press, Cleveland, 1989, 19-37.

3. Künkele U., Lecheler J.: Ratgeber Pollenallergie für Patienten und Arzte. Quintessenz, München, 1992, 69-71.

4. Ariano, R.: Pollinosi "maggiori" e "minori". In: Aerobiologia e allergeni stagionali. Ed.: Ariano, R., Bonifazi, F., Cap 8 Ed. ECIG, 2006.

5. Ogren T. L.: Allergy-Free Gardening - The Revolutionary Guide to Healthy Landscaping, Ten Speed Press, Berkeley, Toronto, 2000.

6. Hruska K:: Assessment of urban allergophytes using an allergen index, Aerobiologia, , 2003, 19, 107-111, https://doi.org/10.1023/A:1024450601697

7. Ianovici, N.: Aerobiological monitoring of allergenic flora in Timisoara. Lucrări ştiinţifice, Seria Horticultură, 2008, 51, 131-136.

8. Staffolani, L., Velasco-Jimenez, M. J., Galán, C., \& Hruska, K.: Allergenicity of the ornamental urban flora: Ecological and aerobiological analyses in Cordoba (Spain) and 
Ascoli Pivceno (Italy). Aerobiologia, 2011, 27, 239-246. https://doi.org/10.1007/s10453-0109193-8

9. Bergmann K., Zuberbier T., Augustin J., Mücke H., Straff W.: Climate change and pollen allergy: cities and municipalities should take people suffering from pollen allergy into account when planting in public spaces. Allergo J., 2012, 21(2), 103-7. https://doi. org/10.1007/s15007-012-0045-4

10. Cariñanos P., Adinolfi C., Díaz de la Guardia C.: Characterization of Allergen Emission Sources in Urban Areas. J. Environ. Qual. 2016, 45, 244-252, https://doi.org/10.2134/ jeq2015.02.0075

11. Thibaudon, M., Monnier, S., Sindt, C., Oliver, G.: Pollen allergy potency for the main urban plants. EAACl, S0533, Helsinki, 2017.

12. Feliziani, V:: Pollini di interesse allergologico: Guida al loro riconoscimento. Masson Italia Ed., 1986.

13. Corsico, R., Falagiani, P., Ariani, R., Berra, D., Biali, C. et al.: An epidemiological survey on the allergological importance of some emerging pollens in Italy. Alergia e Inmunología, 2000, 10 (3), 155-61.

14. www.pollenlibrary.com

15. Lorenzoni-Chiesura, F., Giorato, M., Marcer, G.: Allergy to pollen of urban cultivated plants. Aerobiologia, 16 (2), 2000, 313-316. https://doi.org/10.1023/A:1007652602113

16. Arnold E., Strohbach M.W., Warren P.S.: Allergenic potential of street trees in Boston, Massachusetts. In: Human-environmental interactions in cities: Challenges and opportunities of urban land use planning and green infrastructure. Eds.: Kabisch, N., Larondelle, N., Reeve, A. Cambridge Scholars Publishing. pp., 2014, 115-141.

17. Ortolani C., Previdi M., Sala G., Bozzoli Parasacchi V., Ortolani A., Minella C.: Allergenicità delle piante arboree e arbustive destinate al verde urbano italiano. Revisione Sistematica e Raccomandazioni basate sull'evidenza. Eur. J. Aerobiology Environ. Med. 2015, (1), 4-123.

18. Karatzas, K. D., Riga, M., Smith, M.: Presentation and dissemination of pollen information. In: Allergenic pollen. Eds.: Sofiev, M., Bergmann, K.C. Springer, Dordrecht, 2013, 217-247 https://doi.org/10.1007/978-94-0074881-1_7

19. Gehrig, R., Gassner, M., Schmid-Grendelmeier, P.: Alnus $\times$ spaethii pollen can cause allergies already at Christmas. Aerobiologia, 2015, 31 (2), 239-247. https://doi.org/10.1007/ s10453-014-9360-4

20. Ragg, M.: The Low Allergy Garden. Hodder \& Stoughton, 1998 
21. Huntington, L: Low-allergen Gardening. Mitchell Beazley Publisher, London, 1998

22. Villaveces, J. W.: Tree allergy and the streettree guide. J. Asthma Res. 1973, 11 (2), 47-56. https://doi.org/10.3109/02770907309100278

23. Magyar D., Mányoki G., Zséli Gy., Szigeti T.: Közegészségügyi szempontok a közterületi sorfák jegyzékéhez. In: Szabó K.: Közterületi Sorfák Jegyzéke. Magyar Díszkertészek Szövetsége, Budapest, 2019, 1-41.

24. Benito Garzón, M., Sánchez de Dios, R., \& Sainz Ollero, H.: Effects of climate change on the distribution of Iberian tree species. Appl. Veg. Sci., 2008, 11 (2), 169-178. https:// doi.org/10.3170/2008-7-18348

25. Jackson, S. T., Sax, D. F: Balancing biodiversity in a changing environment: extinction debt, immigration credit and species turnover. Trends Ecol. Evol., 2010, 25 (3), 153-160. https://doi.org/10.1016/j.tree.2009.10.001

26. Eisenman, T. S., Jariwala, S. P., \& Lovasi, G. S.: Urban trees and asthma: a call for epidemiological research. The Lancet Respiratory Medicine, 2019, 7(7), e19-e20. https://doi. org/10.1016/S2213-2600(19)30193-6

27. Thompson, J. L., Thompson, J. E.: The urban jungle and allergy. Immunol. Allergy Clinics North America, 2003, 23 (3), 371-387. https:// doi.org/10.1016/S0889-8561(03)00006-7
28. Navés-Viñas, F., Pujol Solanich, J., Argimon de Vilardaga, X., Sampere Montlló, J.: El árbol en Jardinería y Paisajismo (Trees in gardening and landscaping). Omega, Barcelona, 1995

29. Horak, F., Jäger, S.: Die Erreger des Heufiebers. Urban \& Schwarzenberg, München, 1979

30. Moulton, A. D., Mercer, S. L., Popovic, T., Briss, P. A., Goodman, R. A., Thombley, M. L., ... \& Fox, D. M.: The scientific basis for law as a public health tool. Am. J. Public Health, 2009, 99 (1), 17-24. https://doi.org/10.2105/ AJPH.2007.130278

31. Landis, T. D., Dumroese, R. K.: Care and handling of container plants from storage to outplanting. International Plant Propagators' Society, Combined Proceedings, 2010, 60, 263-272.

32. Association Française de Science Politique: Projet d'arrêté relatif à l'information préalable devant être délivrée aux acquéreurs de végétaux susceptibles de porter atteinte à la santé humaine (Rendelettervezet az emberi egészséget valószínűleg károsító növények vásárlóinak kiadandó előzetes tájékoztatásról) (NOR : AFSP1623107A), 2019.

33. Heeter, E. M. Chance of Rain: Rethinking Circumstantial Evidence Jury Instructions. 
Hastings Law Journal, 2012, 64, 527-560.

34. Black, B.: A unified theory of scientific evidence. Fordham L. Rev., 1987, 56, 595.

35. Ahuja, J.: UK legal approach to disease causation: examining the role for epidemiological evidence. Doctoral dissertation, University of Birmingham, 2017.

36. Kumar, P., Druckman, A., Gallagher, J., Gatersleben, B., Allison, S., Eisenman, T. S., ... Abhijith, K. V.: The nexus between air pollution, green infrastructure and human health. Envir. Internat., 2019, 133, 105-181. https://doi.org/10.1016/j.envint.2019.105181

37. Cariñanos, P., Casares-Porcel, M., Quesada-Rubio, J-M.: Estimating the allergenic potential of urban green spaces: A case-study in Granada, Spain. Landscape Urban Planning, 2014, 123, 134-144. https://doi. org/10.1016/j.landurbplan.2013.12.009

38. Aalberse, R. C.: Structural biology of allergens. Journal of allergy and clinical immunology, 2000, 106(2), 228-238. https://doi. org/10.1067/mai.2000.108434

39. Benzies, K. M., Premji, S., Hayden, K. A., \& Serrett, K.: State-of-the-evidence reviews: advantages and challenges of including grey literature. Worldviews on EvidenceBased Nursing, 2006, 3(2), 55-61. https://doi. org/10.1111/j.1741-6787.2006.00051.x
40. Givninsh, T. J.: Ecological constraints on the evolution of breeding systems inseed plants: Dioecy and dispersal in gymnosperms. EvoIution, 1980, 34(5), 959-972. https://doi.org/10.1111/j.1558-5646.1980.tb04034.x

41. Nilsson, S., Praglowski, J., Nilsson, L. Atlas of airborne pollen grains and spores in Northern Europe. Natur och kultur. Örebro, 1977.

42. Bassett, I. J., Crompton, C. W., Parmelee, J. A.: An atlas of airborne pollen grains and common fungus spores of Canada. Printing and Publishing Supply and Services Canada, Hull, Québec, 1978.

43. Faegri, K., Kaland, P. E., \& Krzywinski, K.: Textbook of pollen analysis. $\left(4^{\text {th }}\right)$ John Wiley and Sons, Chichester, 1989.

44. Erdtman, G.: Erdtman's handbook of palynology. Munksgaard, Copenhagen, 1992

45. Harley, M. M., Morton, C. M., Blackmore, S. Pollen and spores: morphology and biology. Royal Botanic Gardens, Kew, 2000.

46. Jelks, M.: Allergy pollen key with images. Jelks, M.- FAAAAI, Sarasota, 2001.

47. Beug, H. J.: Leitfaden der Pollenbestimmung für Mitteleuropa und angrenzende Gebiete. Dr. Fiedrich Pfeil, München, 2004.

48. Bucher, E: Lo spettro pollinico dei mieli dell'Alto Adige. Agenzia provinciale per la protezione dell'ambiente e la tutela del 
lavoro, Laboratorio biologico ARPA, Laives, 2004.

49. Halbritter, H. PalDat - A palynological database, 2005.

50. Lacey, M. E.,West, J. S.: The air spora: a manual for catching and identifying airborne biological particles. Springer Science \& Business Media. Dordrecht, 2007, https:// doi.org/10.1007/978-0-387-30253-9

51. Grant-Downton, R.: Pollen terminology. An illustrated handbook. Springer, Wien, 2009. https://doi.org/10.1093/aob/mcp289

52. Travaglini, A., Brighetti, M., Arsieni, A., Vinciguerra, F.: Atlante del polline delle principali specie allergeniche d'Italia. II Raggio Verde edizioni, Lecce, 2014.

53. Erdtman, G.: Pollen analysis. Chronica Botanica Co., Waltham, Mass, 1943.

54. Gregory, P. H.: The microbiology of the atmosphere. Leonard Hill Ltd., London, 1961. https://doi.org/10.5962/bhl.title.7291

55. Krüssmann, G.: Handbuch der Laubgehölze Band I-III. Paul Parey, Berlin-Hamburg, 1976-1978.

56. Krüssmann, G.: Handbuch der Nadelgehölze. 2. Aufl., Parey, Berlin/Hamburg, 1983

57. O'Rourke, M. K., Buchmann, S. L.: Pollen Yield of Two CVS. of Olea europaea L. ('Manzanillo'and 'Swan Hill'). In: Advances in Aerobiology. Eds.: Boehm, G., Leuschner, R. M. Birkhäuser, Basel, 1987, 101-108 https:// doi.org/10.1007/978-3-0348-7491-5_18

58. Járainé, K. M: Allergén virágporok. Élet és Tudomány, 1990, 45:467, 595, 659, 723, 787, 851, 915, 979, 1043.

59. Bricchi, E., Frenguelli, G., Mincigrucci, G.: Experimental results about Platanus pollen deposition. Aerobiologia, 2000, 16(3-4), 347. https://doi.org/10.1023/A:1026701028901

60. Orlóci, L.: Veszélyes hibridciprus. - Kertészet és Szőlészet,2000, 49,13.

61. Hosoo, Y., Yoshii, E., Negishi, K., \& Taira, H.: A histological comparison of the development of pollen and female gametophytes in fertile and sterile Cryptomeria japonica. Sexual Plant Reproduction, 2005, 18 (2), 81-89. https://doi.org/10.1007/s00497-005-0003-3

62. Basky, Z., Ladányi, M., Simončič, A.: Efficient reduction of biomass, seed and season long pollen production of common ragweed (Ambrosia artemisiifolia L.). Urban Forestry Urban Greening,2017, 24, 134-140. https:// doi.org/10.1016/j.ufug.2017.03.028

63. Magyar, D., Gál, V., Jáki-Vékony, D., Szigeti, T.: Hogyan válasszunk növényeket kertünkbe? Egészségtudomány, 2020, 64(1-2), 95-96.

64. https://efop180.antsz.hu/temak-konyezetegeszsegugy/allergenek-a-levegoben/aller- 
Környezetegészségügy - Eredeti közlemény / Environmental health - Original article

genek-hogyan-valasszunk-kertunkbe-fakat-cserjeket.html

65. Magyar, D., Zséli, G., Szigeti, T., Páldy, A., Udvardy, O., Orlóci, L: A növények potenciális allergenitása - áttekintés és módszer- tani javaslat. Egészégtudomány (in press) $2020(4)$

66. Magyar, D.: Mi jöhet még? Invazív allergén növények, AMEGA 2019, 26(3), 20-24. 